\title{
WADAH SOSIAL : OLAHRAGA DAN KETERAMPILAN
}

\author{
Riando Agustian ${ }^{1)}$, Suwandi Supatra ${ }^{2)}$ \\ 1) Program Studi S1 Arsitektur, Fakultas Teknik, Universitas Tarumanagara, riando.315150145@stu.untar.ac.id \\ 2) Program Studi S1 Arsitektur, Fakultas Teknik, Universitas Tarumanagara, ybhan50@gmail.com
}

\begin{abstract}
Abstrak
Kebutuhan akan tempat ketiga (third place) semakin meningkat yang didasari oleh peningkatan angka kebutuhan hidup dan pertumbuhan ekonomi yang mengakibatkan masyarakat hanya terfokus untuk mencari pendapatan yang lebih tinggi dari sebelumnya, sehingga menimbulkan tingket stress yang meningkat. Hal ini juga diperburuk dengan sedikitnya sarana sosial yang dapat digunakan oleh masayarakat sebagai wada bersosialisasi. Oleh sebab itu penulis ingin mencoba untuk menciptakan tempat ketiga (third place) bagi masyarakat disekitar lokasi terpilih. Lokasi yang terpilih adalah di jalan Kayu Putih Raya yang merupakan kawasan perumahan bagi sebagian besar pekerja industri yang ada pada kawasan industri Pulo Gadung. Pemilihan lokasi terpilih juga didasari oleh hasil survei lapangan yang menunjukan masih minimnya sarana bagi masyarakat untuk dapat mendapatkan hiburan yang bersifat tidak berbayar dan tempat untuk berkumpul dan bersosialisasi antar masyarakat. Dalam mendesain proyek ini penulis juga turut serta memasukan analisa tapak secara makro, mezo, dan mikro kedalam pertimbangan pembuatan projek ini. Sehingga projek yang dihasilkan dapat sesuai dengan lingkungan sekitar. Dalam menentukan program penulis juga memasukan hasil kuesioner dalam pertimbangan dalam menentukan program yang tepat bagi masyarakat pada sekitar proyek. Pada akhirnya projek ini dapat didesain oleh penulis dengan data-data yang dikumpulan dari sekitar lokasi proyek dan diharapkan dapat digunakan secara maksimal oleh masyarakat sekitar.
\end{abstract}

Kata kunci: tempat ketiga; tingkat stres; wadah

\begin{abstract}
The need for third place increased based on an increase in the number of necessities of life and economic growth which resulted in the community only focusing on finding a higher income than before, which caused an increase in stress levels. This is also made worse by the lack of social facilities that can be used by the community to socialize. Therefore the writer wants to try to make a third place for the community around the chosen location. The chosen location is on Jalan Kayu Putih Raya which is a residential area for most industrial workers in the Pulo Gadung industrial area. The choice of location chosen was also based on the results of the field survey which showed that there was still a lack of means for the community to get free entertainment and a place to gather and socialize among the people. In designing this project, the writer also included macro, mezo, and micro site analysis in the consideration of making this project. So that the resulting project can be in accordance with the surrounding environment. In determining the program, the authors also include the results of the questionnaire as a consideration in determining the right program for the community around the project. In the end this project can be designed by the writer with data collected from around the project location and is expected to be used optimally by the surrounding community.
\end{abstract}

Keywords: stress level; space third; place 


\section{PENDAHULUAN}

Seiring meningkatnya pertumbuhan ekonomi dan perkembangan teknologi semakin membuat masyarakat hanya terfokus untuk bekerja dan bersifat individualis. Dan segala aktifitas pada umumnya hanya terpusat pada tempat tinggal (first place) dan tempat bekerja (second place). Hal ini berdampak pada menurunya angka interaksi sosial secara langsung, meningkatnya angka penggunaan media sosial dan secara tidak langsung mempengaruhi tingkat kebahagiaan seseorang. Penurunan interaksi sosial juga dipengaruhi oleh kurangnya tempat yang memadai bagi masyarakat untuk dapat bersosialisasi namun tetap dapat mengikuti kepadatan aktifitas setiap individu, dari sinilah terbentuk sebuah kebutuhan akan tempat dimana masyarakat dapat menghabiskan waktu dan melepas kepenatan diluar dari tempat tinggal dan tempat bekerja, tempat tersebut disebut dengan tempat ketiga (Third Place). Pada tempat ini seseorang dapat berinteraksi dengan masyarakat sekitar tanpa dibatasi oleh status sosial dan ekonomi mereka, pada tempat ketiga (Third Place) masyarakat juga dapat melakukan segala aktifitas yang mereka gemari.

Bedasarkan penjabaran diatas proyek ini diusulkan adalah sebuah community center yang berfokus pada bidang olahraga. Pemilihan community center bertujuan untuk membatu memfasilitasi masyarakat untuk dapat berinteraksi secara langsung tanpa adanya unsur komersialisasi yang dapat mempengaruhi seseorang untuk dapat berinteraksi secara langsung, diharapkan dapat menurunkan angka stress level dan kepenatan yang tinggi pada kawasan Pulo Gadung sebagai kawasan industri dan memberikan kebebasan bagi pengguna untuk dapat menggunakan fasilitas ini tanpa adanya rutinitas yang mengikat yang dapat membebani pengguna di kemudian hari. Community center juga diharapkan dapat menghilangkan kesenjangan sosial yang terjadi pada sekitar tapak terpilih, yang masih terlihat jelas pada sekitar tapak. Pemilihan bidang olahraga sebagai fokus utama pada proyek didasari pada kebutuhan masyarakat akan tempat berolahraga yang tinggi yang disimpulkan dari banyaknya fasilitas olahraga yang bersifat komersil dan hasil dari kuesioner yang akan dijelaskan pada bab sejanjutnya. Pemilihan bidang olahraga sebagai fokus utama diharapkan dapat menurunkan angka kesakitan masyarakat yang terbilang tinggi yang mencapai $10 \%$ dari total penduduk (bedasarkan statistik kesejaterahan rakyat kota Jakarta Timur). Proyek ini juga diharapkan dapat mewadahi masyarakat yang ingin mengembangkan keterampilan mereka dalam bidang olahraga untuk menjadi atlet atau profesional dalam bidang olahraga yang digemari.

Proyek ini juga diharapkan dapat meningkatkan minat masyarakat dalam menggunakan tranportasi umum karena berdekatan dengan lokasi stasiun LRT Equestrian sehingga dapat saling mendukung antara proyek dan stasiun LRT. Proyek ini juga diharapkan dapat mendorong masyarakat untuk menjaga kebersihan pada lingkungan masing-masing dengan sistem bank sampah, dimana beberapa fasilitas pada proyek dapat diakses dengan metode pembayaran dengan sampah daur ulang dari tempat tinggal atau tempat kerja mereka.

\section{Visi:}

Menjadikan masyarakat di sekitar proyek menjadi individu yang produktif namun tetap peka terhadap lingkungan dan peduli dengan masyarakat sekitar. Serta meningkatkan kesadaran tentang pentingnya olahraga untuk meningkatkan kesehatan.

\section{Tujuan Proyek}

Proyek bertujuan untuk menyediakan sebuah wadah bagi masyarakat Kayu Putih untuk dapat bersosialisasi dan mendapatkan hiburan yang baik dan sehat tanpa adanya komersialisasi serta membantu memberikan sebuah fasilitas olahraga yang diharapkan dapat meningkatkan kesehatan masyarakat, serta masyarakat dapat menyalukan minat dan bakat mereka dalam bidang olah raga. Proyek ini juga diharapkan dapat memberikan wadah bagi komunitas yang ada pada sekitar lokasi proyek agar dapat mengembangkan atau menambah keterampilan yang mereka punyai, sehingga diharapkan dapat dijadikan sebagai batu loncatan mereka agar dapat berprestasi, membantu pemerintah dalam menaikan minat masyarakat dalam menggunakan 
tranportasi umum, khususnya LRT yang berada dekat dengan lokasi proyek. Hal ini dapat diwujudkan dengan menerapkan sistem park and drive pada proyek. Dan menerapkan konsep perancangan Sustainable Development Goals sebagai acuan utama dalam perancangan proyek agak proyek ini dapat ikut berkontribusi dalam menjaga kelestarian lingkungan.

\section{Sumbangan Proyek Bagi Kehidupan Kota}

Proyek diharapkan dapat mewadahi kebutuhan masyarakat akan sebuah tempat yang dapat menyatukan semua kalangan masyarakat tanpa dibatasi oleh perbedaan sosial, ekonomi, budaya, dan agama. Dan kebutuhan akan sebuah tempat dimana masyarakat dapat melepaskan kepenatan dari akttifitas sehari hari yang menimbulkan stres bagi masyarakat. Proyek ini juga diharapkan dapat memfasilitasi masyarakat dalam mengembangkan minat dan bakat mereka masing-masing dan mendorong usaha ekonomi mandiri.

\section{KAJIAN LITERATUR}

Tipe dan perilaku dalam arsitektur berelasi secara timbal balik. Menurut Quatremere de Quincy, tipe mewakili gagasan tentang elemen yang seharusnya berfungsi sebagai aturan untuk model (Aguidin, 1995). Tipe terbagi ke dalam dua bentuk dasar, yaitu tipe berupa model (klasifikasi berdasarkan kemiripan morfologis) dan tipe berupa ide dari sebuah elemen yang memberikan aturan bagi bentukan model sebagai objek yang diulang (Lee dan Jacoby, 2011). Sedangkan tipologi merupakan ilmu yang mempelajari tentang tipe/konsep yang memilah kelompok objek berdasarkan kesamaan sifat-sifat dasar (Ching, 1979). Perilaku sendiri merupakan cara seseorang atau sesuatu bertindak terhadap subjek/objek lain di sekitarnya dan dapat digunakan untuk memahami korelasi antara kehidupan manusia, alam, dan lingkung bangun menurut Tsukamoto dan Kaijima dalam buku Adaptable Architecture: Theory and practice (2016).

\section{Open Architecture}

Arsitektur berkembang berdasarkan masyarakatnya, dimana selalu dirancang dan direncanankan bukan terbentuk dengan sendirinya. Arsitektur berkembang sesuai dengan perubahan masyarakat dan kebudayaan dimana arsitektur tersebut berada. Seperti sebuah cafe yang mulai bergeser peruntukannya dari hanya sekedar tempat untuk mendapatkan secangkir kopi menjadi tempat untuk bersantai dan berdiskusi. Perubahan ini dikarenakan perubahan gaya hidup masyarakat, yang sebelumnya memiliki banyak waktu luang untuk meminum kopi dan melakukan diskusi di lain waktu menjadi masyarakat yang memiliki kepadatan aktifitas yang sangat tinggi sehingga membuat mereka melakukan beberapa hal disaat yang bersamaan. Pergeseran pada fungsi sebuah cafe diatas menunjukan bahwa arsitektur terus berkembang dan terbuka terhadap perubahan yang terjadi. Pergeseran tipologi cafe menjadi work place membentuk sebuah objek arsitektur baru yang disebut dengan Third Place.

\section{Third Place}

Third Place merupakan sebuah tempat yang akan dikunjungi seseorang diluar rutinitas pada tempat tinggal (fistt place) dan tempat kerja (second place). Third Place dapat diartikan sebagai tempat untuk melepas penat dan lelah ditengah-tengah padatnya aktifitas yang dimiliki setiap harinya. Third Place memiliki beberapa karakteristik agar sebuah tempat tersebut dapat dikatakan sebagai sebuah Third Place. Karakter Third Place munurut Oldenburg (1999) adalah

- Terletak pada tempat yang netral.

Tempat netral sendiri diartikan sebagai sebuah kawasan yang tidak dimiliki oleh suatu kelompok tertentu yang dapat membatasi orang untuk dapat berkunjung ke kawasan tersebut. Sehingga semua orang dapat berkunjung dan pergi sesuai dengan keingin mereka masing-masing tanpa adanya paksaan dari pihak luar. 
- Merupakan sebuah tempat yang menyamaratakan

Tempat ketiga sendiri harus bersifat untuk semua orang tanpa dibatasi oleh status sosial dan ekonomi yang ada. Sehingga semua kalangan baik yang memiliki status sosial yang tinggi maupun yang rendah harus dapat berbaur menjadi satu tanpa adanya perbedaan kelas diantara mereka.

- Interaksi sosial menjadi fokus utama aktifitas

Sebuah Third Place harus memiliki kegiatan utama pertukaran informasi secara lisan sehingga sebuah Third Place harus dapat menyediakan sebuah tempat dimana masyarakat dapat berkumpul dan bertukar informasi.

- Bersifat kekeluargaan

Pada Third Place harus dapat menciptakan sebuah tempat dimana seseroang merasa nyaman satu dengan yang lain pada tempat tersebut.

- Tempat yang menyenangkan

Tempat ketiga harus dapat menciptakan kegiatan menyenangkan sehingga membuat seseorang ingin datang kembali.

- Reguler

Tempat ketiga harus dapat menjadi bagian dari rutinitas pengunjungnya sehingga Third Place harus menciptakan suatu daya tarik yang membuat seseorang ingin datang kembali mengunjungi tempat tersebut secara reguler.

- Kemudahan dalam akses menuju Third Place

Third Place harus berlokasi dekat dengan pusat aktifitas dari target pengunjung yang diinginkan sehingga memudahkan pengunjung dalam mengunjungi Third Place. Oleh karena itu Third Place sangat berkaitan dengan waktu dan lokasi. Seberapa besar waktu yang dibutuhkan untuk mengunjungi lokasi tersebut dan seberapa dekat Third Place dengan lokasi pusat aktifitas.

\section{Community center}

Sebuah community center sendiri dapat dikatakan sebagai salah satu contoh dari tempat ketiga yang paling mudah dijumpai. Hal ini dikarenakan sebuah community center bersifat terbuka untuk semua orang dan dijadikan sebagai sarana untuk berinteraksi sosial bagi lingkungan di sekitar community center itu berada. Community center pada umumnya memiliki kegiatan utama berupa interaksi sosial antara masyarakat. Berikut adalah penjelasan mengenai definisi, arti dan kegiatan dari community center.

\section{Pengertian Komunitas}

Menurut Komunitas Hendro Puspito (2018) merupakan suatu kelompok sosial yang nyata dan terdiri dari individu-individu dengan berbagai peran dan berbagai latar belakang yang mempunyai satu tujuan tertentu. Dalam ilmu sosial, komunitas memiliki arti sebagai kelompok yang terbagi dalam beberapa organisme yang melakukan kegiatan sosial karena memiliki ketertarikan dan habitat yang sama.

Komunitas dibedakan menjadi 3 komponen, yaitu :

- Berdasarkan lokasi/tempat, dalam komponen ini sebuah komunitas terbentuk karena adanya interaksi di Antara beberapa orang/kelompok yang tinggal di wilayah yang sama.

- Berdasarkan minat, komunitas ini terbentuk karena adanya interaksi orangorang karena adanya minat yang sama pada satu bidang tertentu. Misalnya komunitas musik, komunitas seni, kominitas pecinta alam, dan sebagainya.

- Berdasarkan komuni, komunitas ini adalah komunitas yang terbentuk berdasarkan ide-ide tertentu yang menjadi landasan dari komunitas itu sendiri. 


\section{Pengertian Community center}

Dalam Penjelasan sebelumnya telah dijelaskan bahwa Komunitas (Community) merupakan kelompok sosial yang nyata dan terdiri dari individuindividu dengan berbagai peran dan berbagai latar belakang yang mempunyai satu tujuan tertentu. Pusat memiliki arti Suatu bagian yang di khususkan, atau suatu tempat yang mewadahi suatu kegiatan tertentu, sehingga pusat komunitas merupakan tempat atau lokasi publik di mana anggota komunitas cenderung berkumpul untuk kegiatan kelompok, dukungan sosial, informasi publik, dan keperluan lainnya. Mereka kadangkadang terbuka untuk seluruh masyarakat atau untuk kelompok khusus dalam masyarakat yang lebih besar. Contoh pusat - pusat komunitas untuk kelompok khusus meliputi: pusat komunitas Islam, pusat komunitas Kristen, pusat komunitas Kebudayaan, karang taruna dan lain lain. Dengan kata lain, bangunan pusat komunitas juga dapat diartikan sebagai tempat di mana anggota komunitas dapat berkumpul untuk kegiatan sosial, pendidikan, dan budaya. Menurut Crow dan Allan (2002), Pusat Komunitas dapat tebagi menjadi 3 komponen, yaitu

- Berdasarkan lokasi tempat, dalam komponen ini sebuah komunitas dapat terbentuk karena adanya interaksi di antara beberapa orang kelompok yang tinggal di wilayah yang sama.

- Berdasarkan minat, komunitas dapat terbentuk karena adanya interaksi antara orang-orang yang memiliki minat yang sama pada satu bidang tertentu, contohnya: komunitas musik, komunitas seni, komunitas pecinta alam dan sebagainya.

- Berdasarkan Komuni, komunitas ini adalah komunitas yang terbentuk berdasarkan ide - ide tertentu yang menjadi landasan dari komunitas itu sendiri, contohnya: sebuah perguruan silat, sebuah partai politik dan yang lainnya.

\section{METODE}

Metode yang digunakan dalam perancangan wadah sosial ini adalah metode pengamatan lapangan, tipologi, serta analisis-analisis terhadap lingkungan tapak secara makro, mezo, dan mikro. Selain itu, tema konsep yang diangkat turut menjadi bagian dari proses merancang.

\section{Analisis Makro}

Pemilihan kawasan berada pada kawasan industi Pulogadung yang menjadi salah satu pusat industri di Jakarta. Pemilihan kawasan industri sebagai lokasi proyek dikarenakan memiliki tingkat stress level yang tinggi. Stress level yang tinggi disebabkan angka mobilitas yang tinggi dan tingkat kepenatan yang besar akibat melakukan kegiatan saya sama setiap harinya. angka mobilitas yang tinggi juga berdampak pada pergerseran cara bersosialisasi dari bersosialisasi secara langsung menjadi media sosial sebagai sarana untuk bersosialisasi. Pergeseran ini juga didorong oleh minimnya fasilitas sosial yang baik bagi masyarakat sekitar kawasan industri, hal ini disebabkan pembangunan hanya terfokus pada industri.

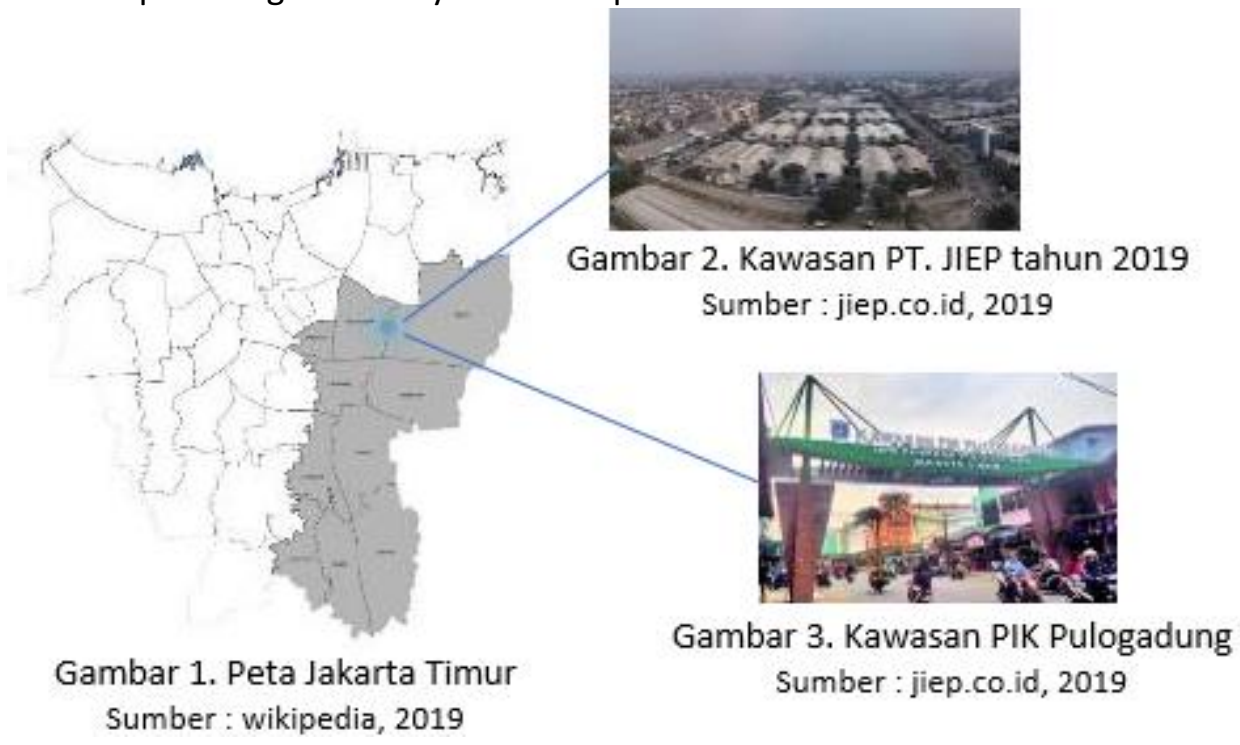


Kecamatan Pulo Gadung terpilih dikarenakan lokasi yang masih berdekatan dengan kawasan industri PuloGadung dan menjadi kawasan yang sedang berkembang dengan pesat hal itu ditunjukan dari pembangunan rute LRT pada kawawasan Pulo Gadung. Kecamatan Pulo Gadung juga masih didominasi oleh pekerja pekerja industrian atau kerajinan dan wiraswasta yang merupakan target utama dari proyek.

Tabel 1. Persentase masyarakat bedasarkan pekerjaan

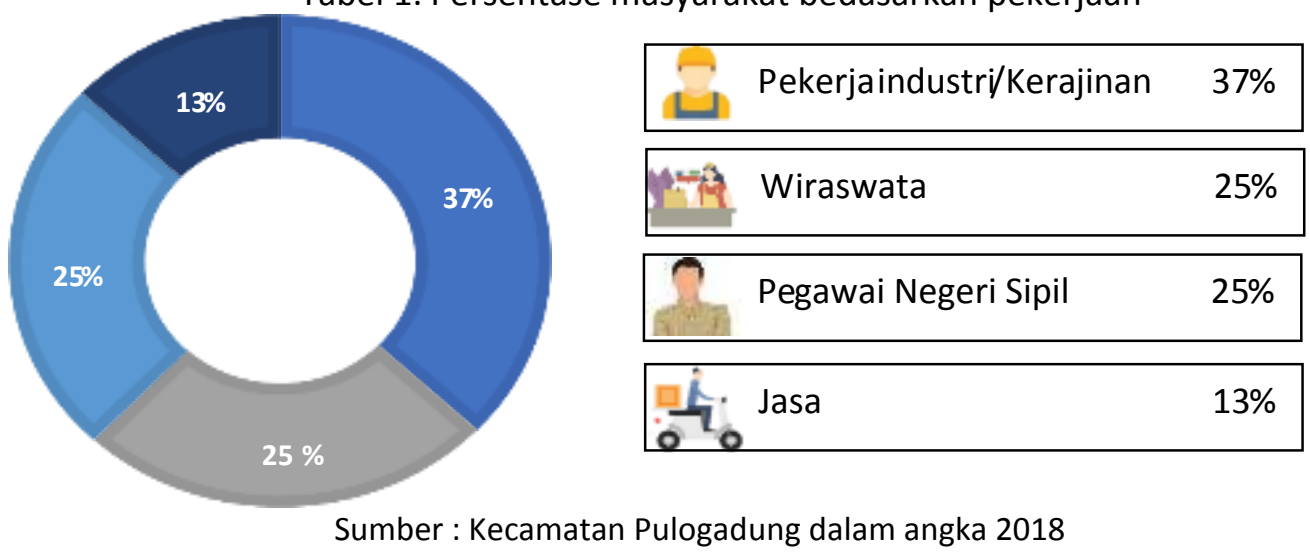

Bedasarkan tabel diatas dapat disimpukan bahwa kawasan terpilih merupakan kawasan yang memiliki tingkat stres yang tinggi yang disebabkan sebagian pekerjaan masyarakat sekitar merupakan pekerja industri yang memiliki jam kerja yang tinggi namun pada umumnya tidak sebanding dengan pendapatan yang diterima.

\section{Analisis Mezo}

Bedasarkan hasil pengamatan lapangan, lokasi terpilih dilalui oleh beberapa sarana transportasi umum diantaranya JAK-59, LRT, U-04, JAK-33. Sehingga tapak terpilih merupakan lokasi yang tepat untuk digunakan pada proyek ini, hal ini dikarenakan sebuah tempat ketiga harus mudah dicapai oleh masyarakat sekitar. Dengan banyaknya sarana transportasi umum yang melewati lokasi terpilih juga diharapkan dapat mendorong angka penggunaan transportasi umum pada masyarakat.

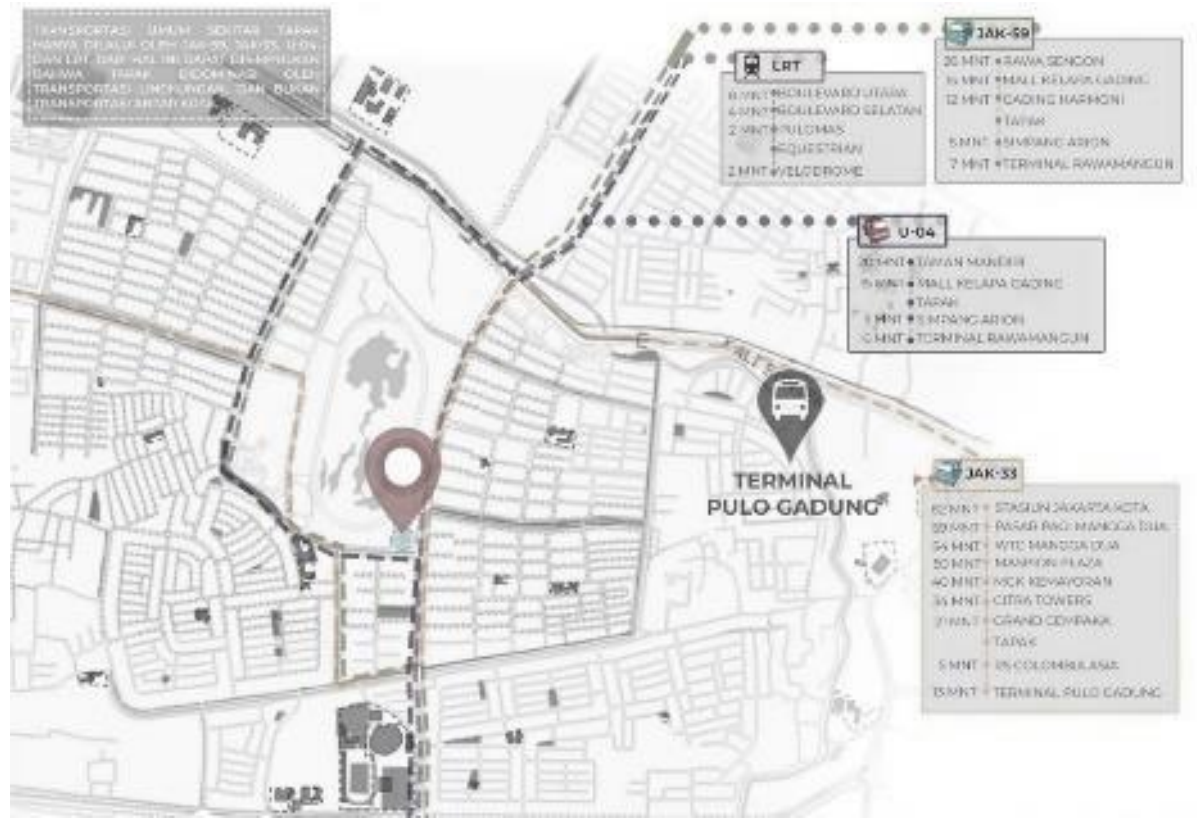

Gambar 4. Analisa tranportasi umum Sumber: Penulis, 2019 
Lokasi terpilih juga memiliki 3 akses utama bagi pejalan kaki menuju tapak. Akses utama merupakan pejalan kaki yang berasal dari stasiun LRT, akses kedua merupakan pejalan kaki yang berasal dari perumahan yang berada di sebelah timur tapak, akses ketiga merupakan pejalan kaku yang berasal dari perumahan yang berada di sebelah selatan tapak dan para pengguna transportasi umum yang ingin mengunjungi tapak.

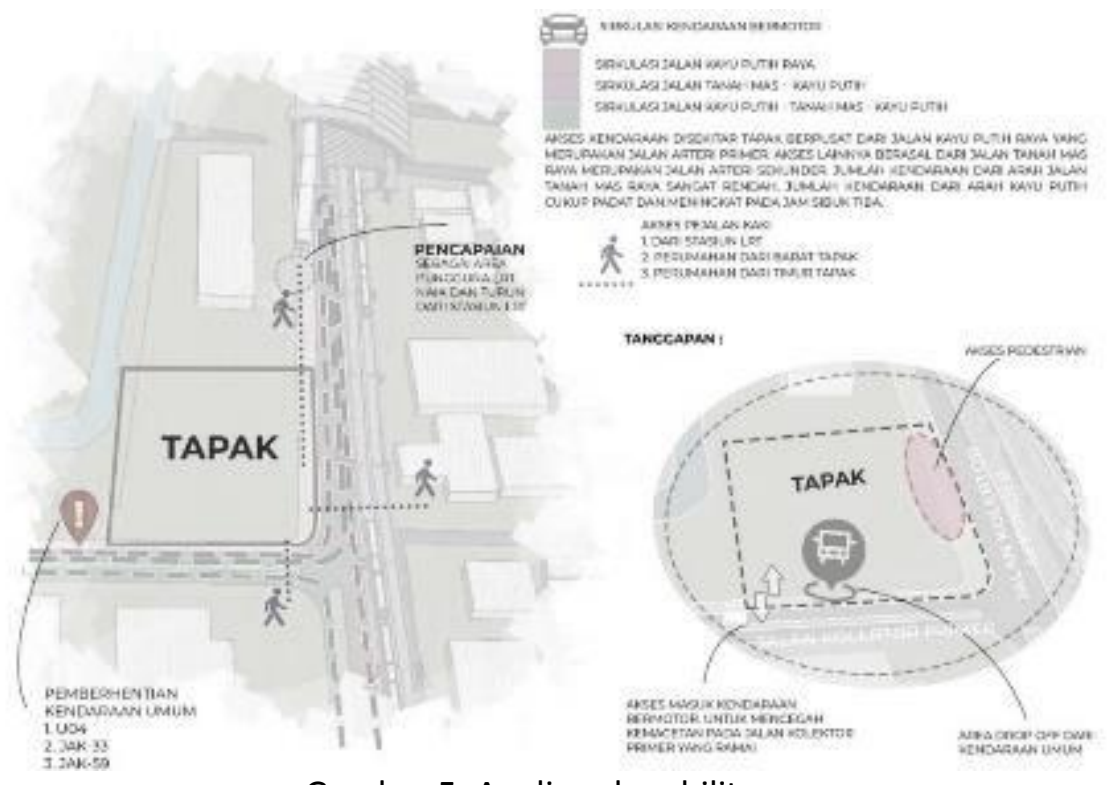

Gambar 5. Analisa aksesbilitas

Sumber: Penulis, 2019

\section{Analisa Mikro}

Bedasarkan hasil analisa tapak terpilih memiliki beberapa view dalam ke luar tapak. View terbaik merupakan view yang berorientasi pada Jakarta International Equestrian Park, dan diikuti oleh view yang berorientasi pada Jalan Tanah Mas Raya. Tapak juga memiliki beberapa view yang kurang baik diantaranya view yang berorientasi pada Jalan Kayu Putih Raya dan pusat perbelanjaan Superindo.

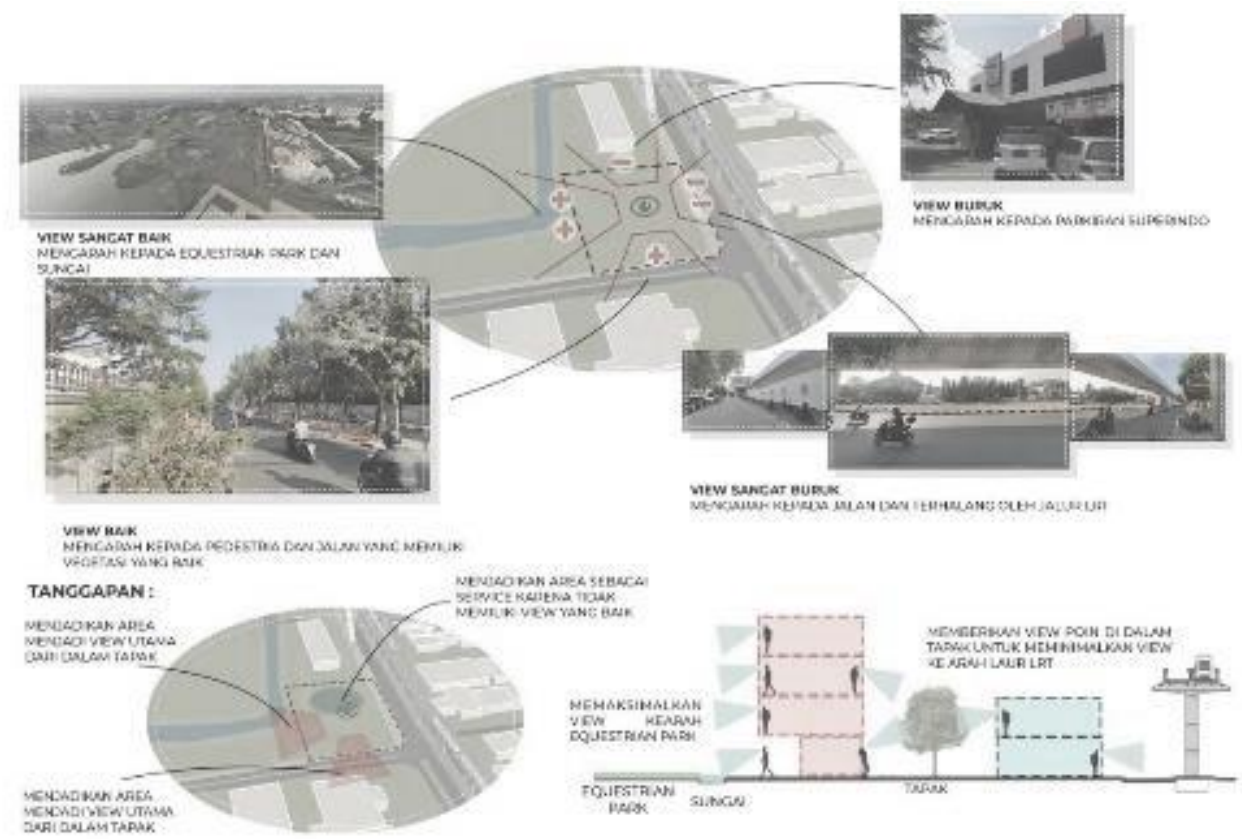

Gambar 6. Analisa view dari dalam ke luar tapak

Sumber: Penulis, 2019 
Selanjutnya merupakan analisa view dari luar menuju dalam tapak. Pada tapak terpilih memiliki 3 view utama, yaitu dari Jalan Tanah Mas Raya, Jalan Kayu Putih Raya, dan dari LRT. Area pada tapak yang paling banyak terlihat adalah persimpangan antara Jalan Tanah Mas Raya dan Jalan Kayu Putih Raya dan sisi sebelah timur tapak yang bersebelahan langsung dengan Jalan Kayu Putih Raya.
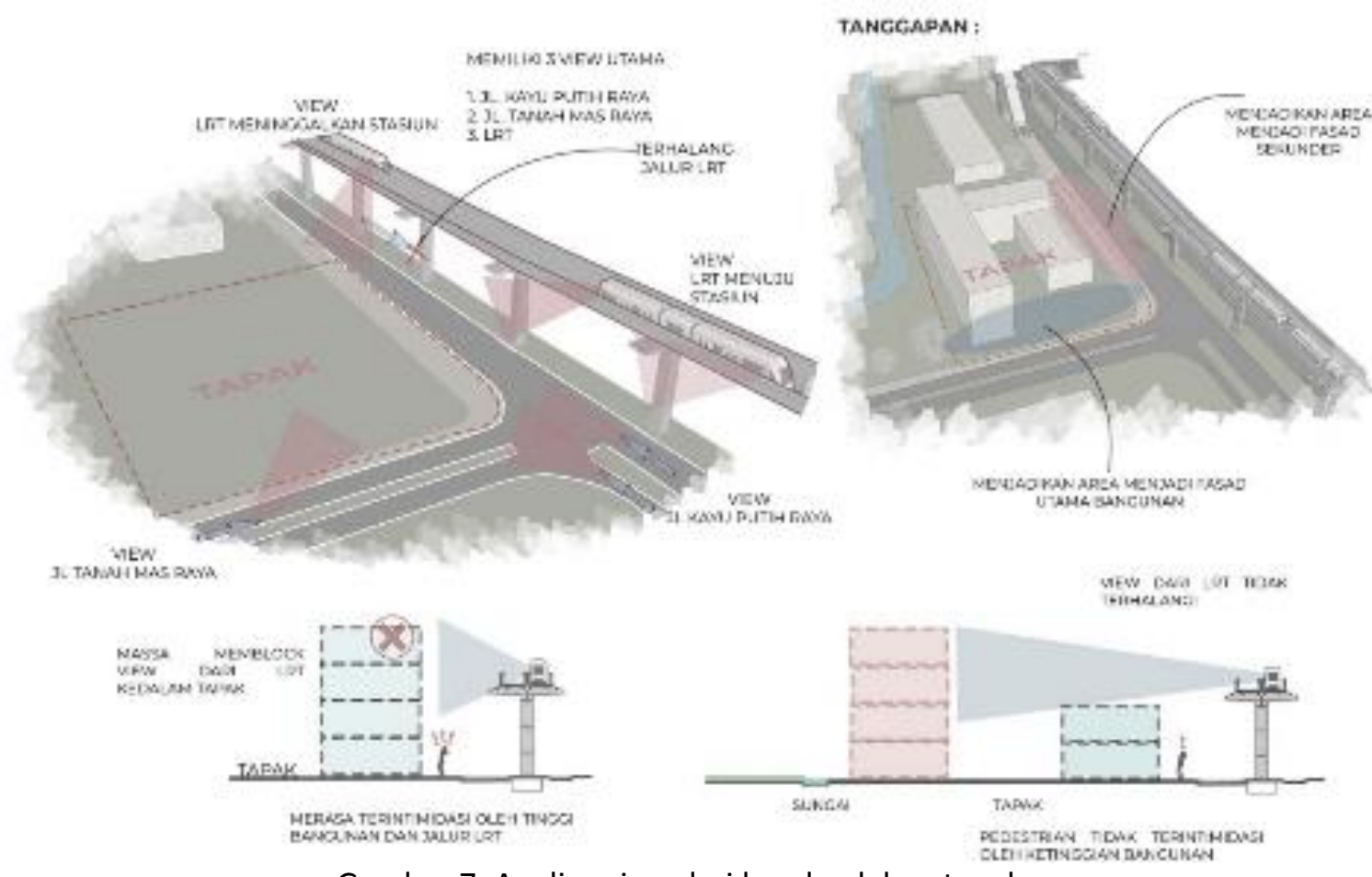

Gambar 7. Analisa view dari luar ke dalam tapak

Sumber: Penulis, 2019

\section{DISKUSI DAN HASIL}

\section{Lokasi}

Lokasi terpilih berada Tapak terletak pada Jl. Tanah Mas Raya RW.16, Kayu Putih , Kec. Pulo Gadung, Kota Jakarta Timur. Lokasi tapak tersebut dipilih bedasarkan beberapa pertimbangan dan anilisa yang sudah dijelaskan pada uraian diatas, sehingga tapak terpilih dapat sesuai dengan proyek yang akan dikerjakan.

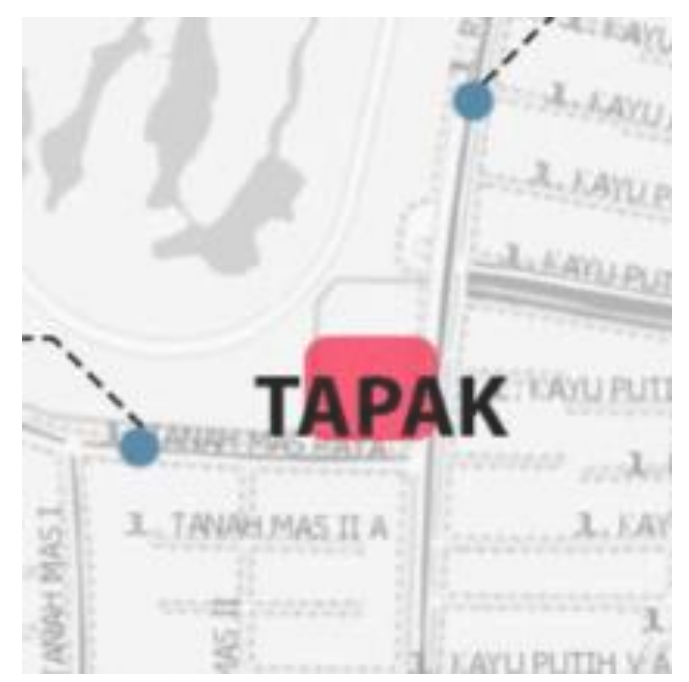

$\begin{array}{ll}\text { Kode Block } & : 03 \\ \text { Sub Block } & : 020 \\ \text { Sub Zona } & : \text { K.1 } \\ \text { KDB } & : 40 \\ \text { KLB } & : 1.6 \\ \text { KDH } & : 30 \\ \text { KB } & : 4 \\ \text { KTB } & : 55 \\ \text { TIPE } & : T \\ \text { LUAS TAPAK } & : 3.500 \mathrm{M} 2\end{array}$

Gambar 8. Peta lokasi tapak.

Sumber : jakarta satu, 2019 


\section{Program Proyek wadah sosial}

Program yang disediakan dalam proyek wadah sosial bersifat fisik dan juga mental/spiritual dengan perincian sebagai berikut.

Tabel 2. Persentase program utama bangunan

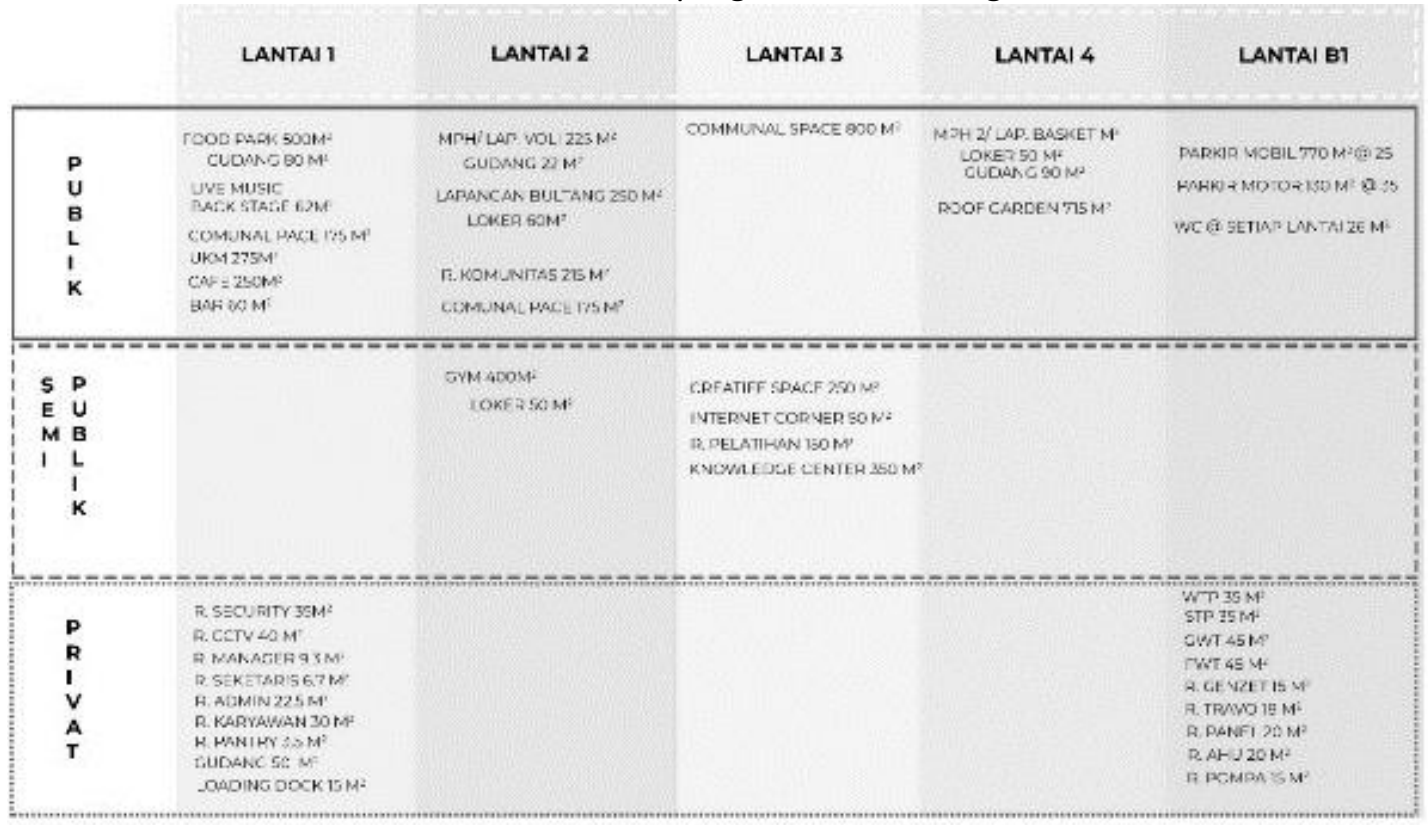

Sumber: Penulis, 2019

\section{Konsep Perancangan wadah sosial dan Proses Gubahan Massa}

Konsep perancangan proyek ini dilatarbelakangi kondisi iklim tropis (massa bangunan dibuat tipis), alur sirkulasi yang dibuat memusat-menyebar (memperjelas alur), dan tema alam sehubungan dengan fungsi proyek yang bersangkutan dengan penyembuhan, ketenangan, dan relaksasi. Dari ketiga latar belakang tersebut, konsep yang diangkat adalah konsep sumur langit/courtyard, sehingga hasil rancangan terintegrasi dengan alam, pencahayaan dan pengudaraan alami maksimal, dan terjadi penyatuan antara ruang dalam dan ruang luar.

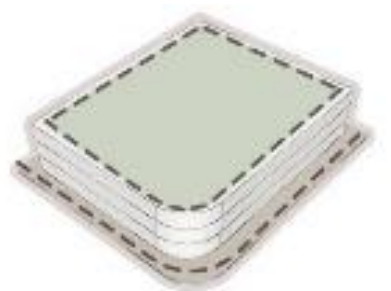

GUBAHAN AWAL

MENGIKUT RENTUK TAPAK DAN MFHAKSIMAI KAN LUAS DAN

KETINCCIAN BANGUNAN

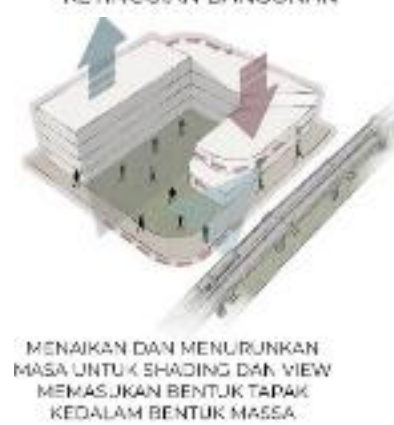

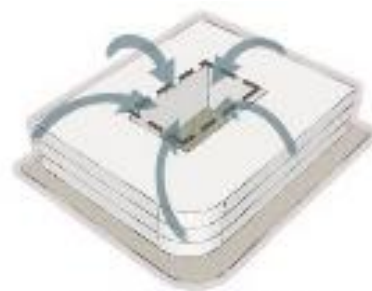

MLMLLNT UK GULAI IAN BEFORIENIASI KEDDALAM TAPAK

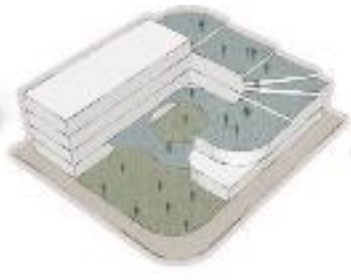

ME STSKS MAL KAN KOO JNS SPACE PAOA BANGU YAK

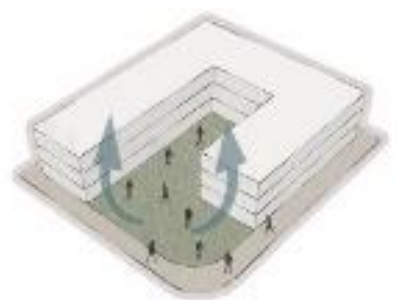

MEMEERIKAN AKSES BACII DFDFSTEIAN DAN BFRFUNGSI SFRACAII TITIKTANCKAP MASSA

Gambar 9. Design Scheme Sumber: Penulis, 2019 
Massa bangunan bermula dari tanggapan terhadap cahaya matahari barat serta alur sirkulasi pengunjung yang menghasilkan posisi massa serta ruang terbuka hijau pada tapak. Kemudian konsep sumur langit diintegrasikan, courtyard disatukan sekaligus disesuaikan dengan bentuk bangunan sekitar serta faktor pandangan pengunjung dari arah Jalan Panjang. Massa yang sudah terbentuk dibuat bertingkat untuk program kegiatan yang lebih bersifat privat dengan area servis ditempatkan pada lantai basement. Setelah itu sirkulasi vertikal diposisikan sesuai standar jangkauan untuk keadaan darurat, dan pada akhirnya massa direduksi agar tidak masif dan disesuaikan dengan kebutuhan program proyek.

Pembagian zoning pada proyek terbagi dalam beberapa kategori yaitu area publik, area servis dan area komersial. Pada proyek area komersial diletakan pada lantai dasar pada bangunan hal ini bertujuan untuk memaksimalkan pendapatan pada area komersial. Pada lantai 2 dan 3 didominasi oleh area publik yang dapat digunakan oleh semua orang dan tidak bersifat berbayar. Pada lantai 4 merupakan area ruang serbaguna dan lapangan basket. Denah lantai basement dikhususkan untuk area servis, utilitas (berkaitan dengan hal-hal mekanikal, elektrikal, dan plumbing), dan area parkir kendaraan pengunjung. Denah lantai dasar diisi ruang-ruang yang bersifat publik seperti area penerimaan (lobi), restoran, area perkebunan, ukm dan live music. Lantai dua diisi dengan area gym, studio fitness serta lapangan bulutangkis dan jogging track . Lantai tiga berisi area knowledge center dan mini auditorium.

\section{Exploded denah}

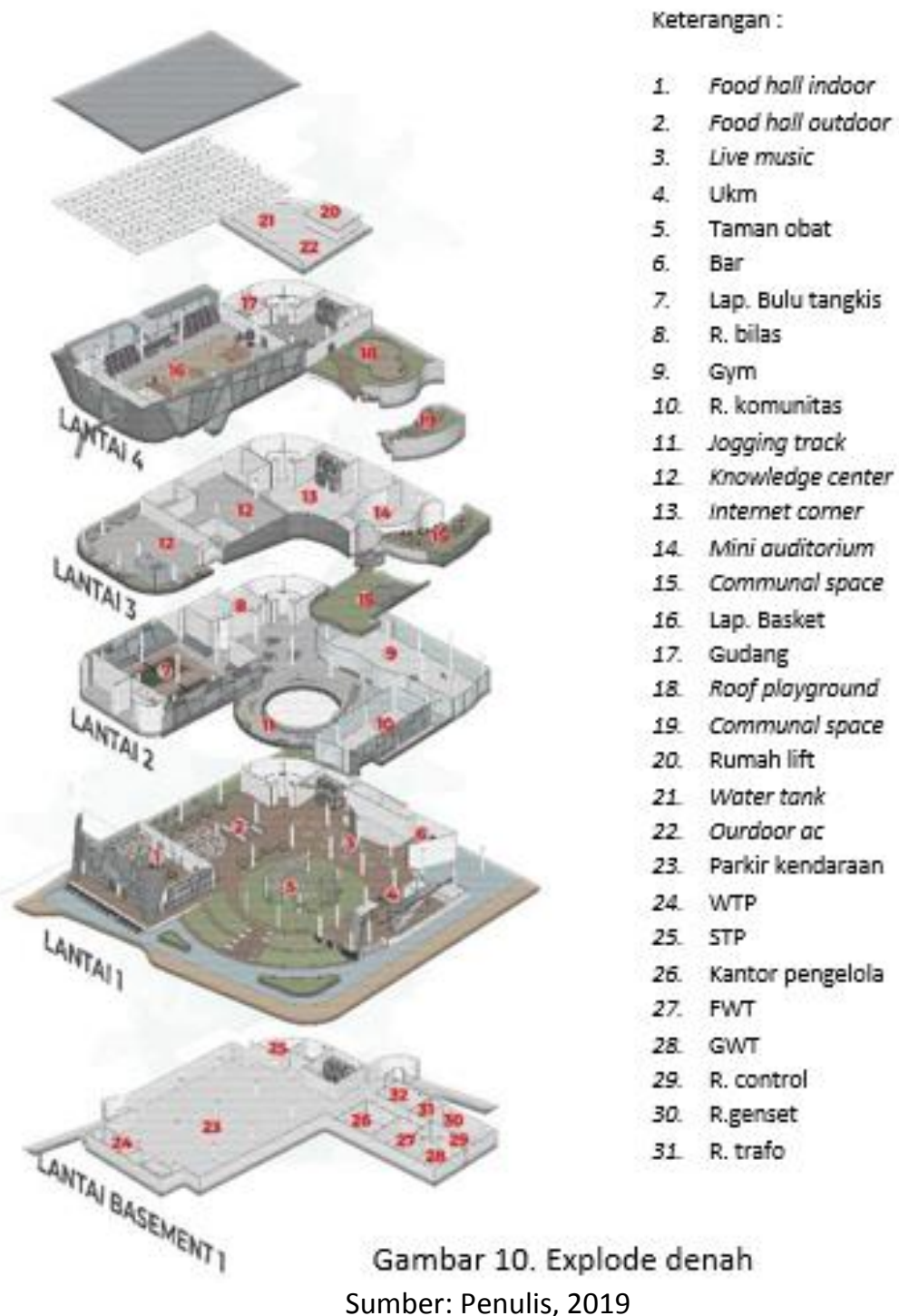




\section{Tampak Bangunan}

Tampak depan bangunan (menghadap Jalan Panjang, sisi timur) dibuat dengan bukaan jendela dalam jumlah yang cukup untuk memaksimalkan cahaya alami yang masuk ke dalam bangunan. Tampak belakang bangunan (menghadap kawasan perumahan, sisi barat) dibuat dengan bukaan yang minim serta fasad berkisi-kisi yang lebih banyak (menghalau sinar barat).

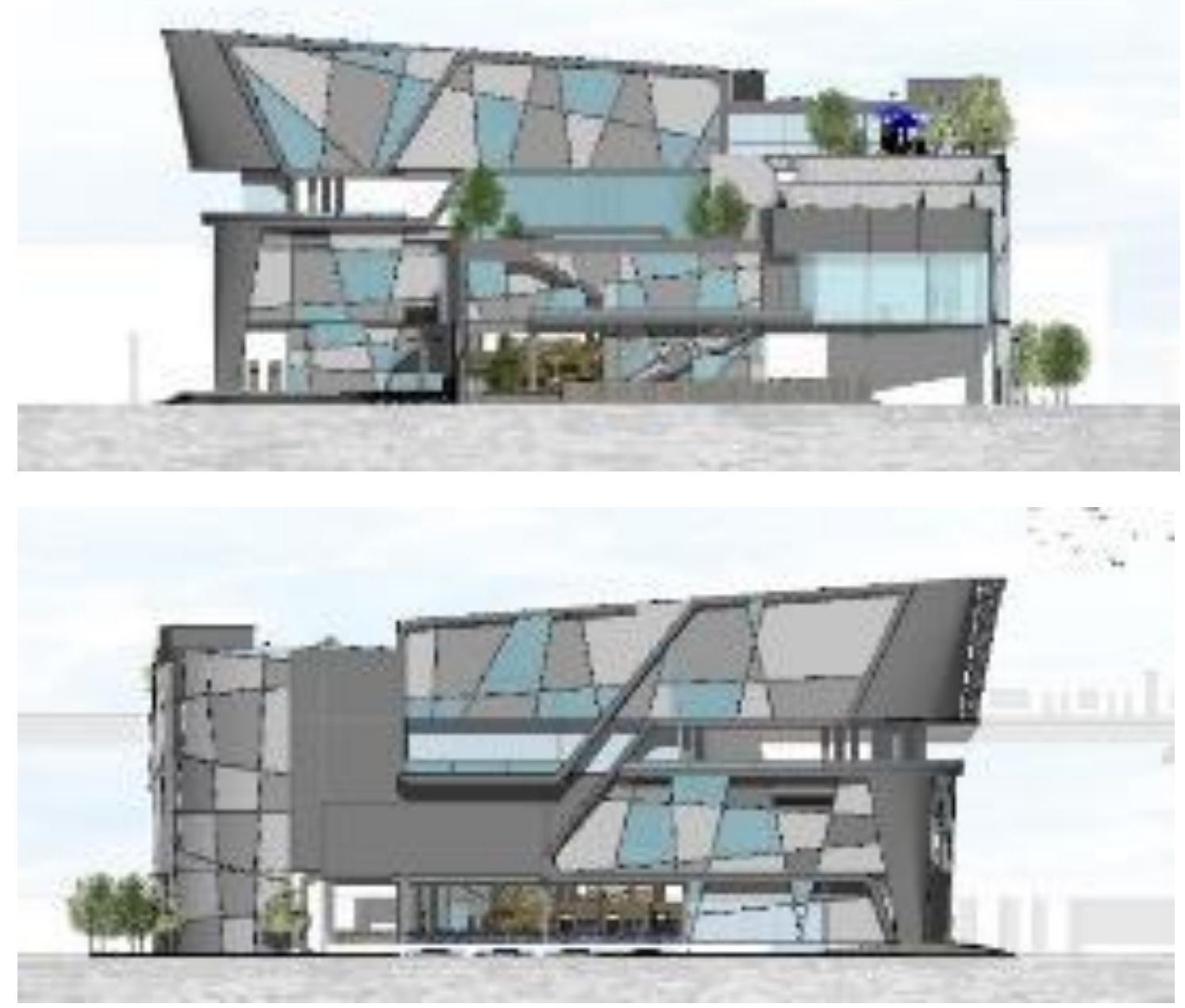

Gambar 11. Tampak Depan (Sisi Timur) dan Tampak Belakang (Sisi Barat) Sumber: Penulis, 2019

Tampak samping kanan menghadap area ruko setinggi 4 lantai dengan fasad berkisi-kisi yang padat (masalah pandangan) dan berundak agar selaras dengan siluet bangunan. Tampak samping kiri yang menghadap apartemen 20 lantai dibuat dengan bukaan kecil karena masalah pandangan dan meminimalkan tereksposnya area servis bangunan dari pandangan pengunjung. Bangunan menggunakan bahan beton bertulang sebagai bahan sistem konstruksinya (kolom dan balok) serta rangka atap baja siku. Fasad bangunan berbahan wood plastic composite (WCP) sehingga lebih tahan lama dan secara visual terlihat alami (seperti kayu). 

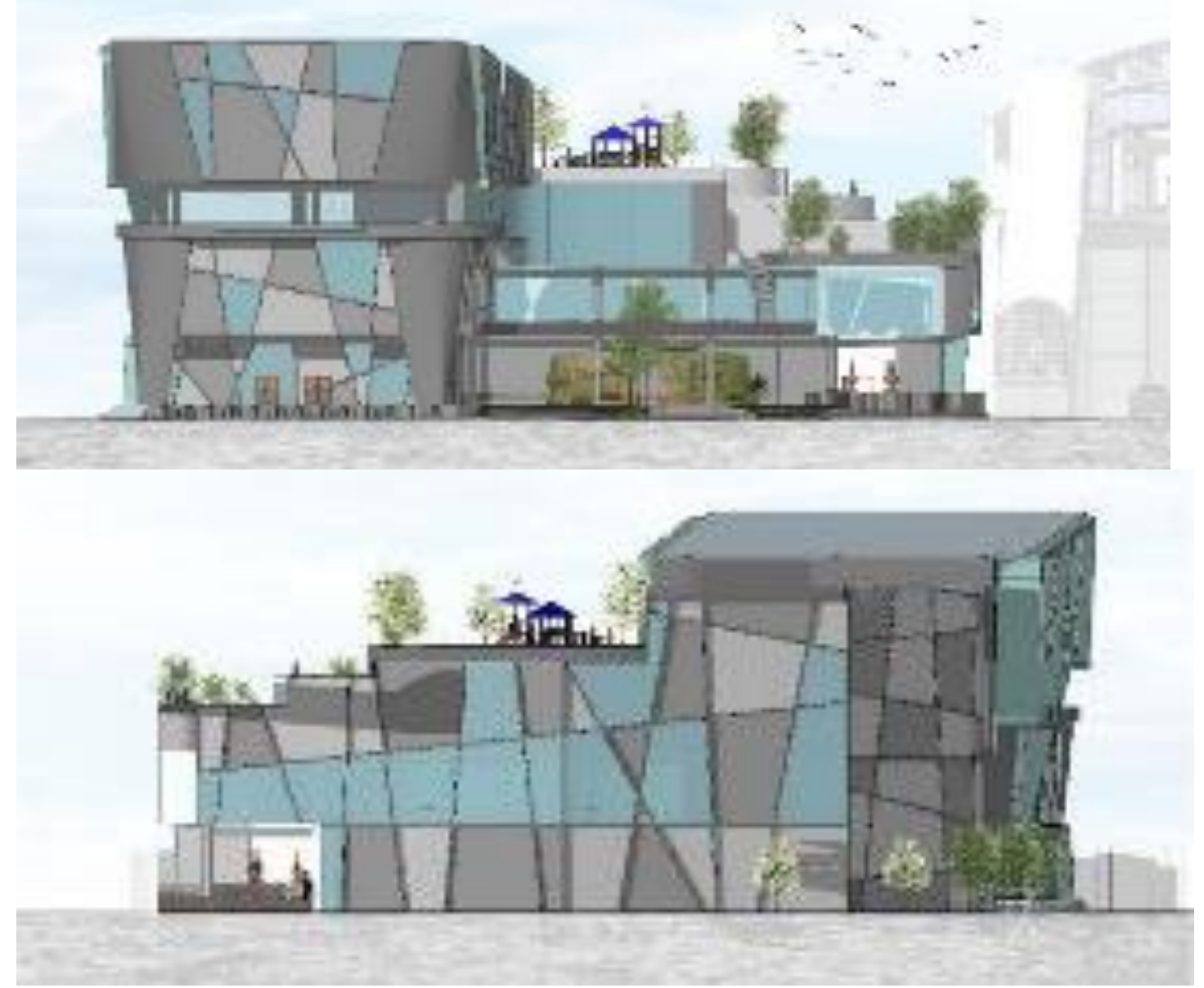

Gambar 12. Tampak Samping Kanan (Sisi Utara) dan Tampak Samping Kiri (Sisi Selatan) Sumber: Penulis, 2019

\section{Perspektif Eksterior Bangunan}

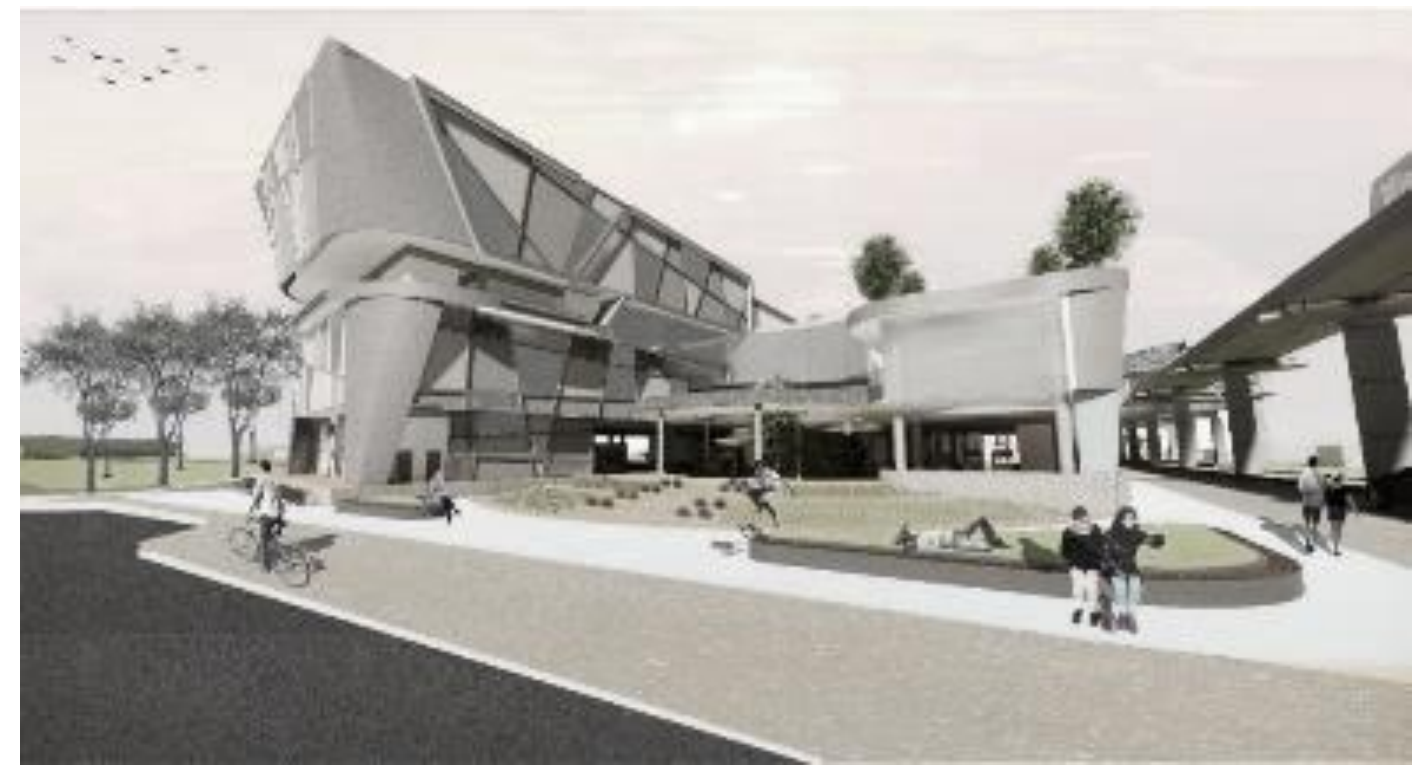

Gambar 13. Perspektif dari jalur pedestrian

Sumber: Penulis, 2019 


\section{KESIMPULAN DAN SARAN}

Proyek wadah sosial di pulogadung , Jakarta Barat diharapkan dapat memberi manfaat positif bagi lingkungan serta membantu menggerakkan pola hidup urban yang lebih sehat, seimbang, dan holistik sehingga kualitas hidup masyarakat dapat meningkat, begitu juga dengan produktivitas serta kebahagiaan. Dengan memberikan program kegiatan pada bangunan berupa live music, food hall, roof garden, dan communal space diharapkan dapat memberikan masyarakat sebuah wadah untuk bersosialisasi. Program sarana olahraga juga diharapkan dapat mengurangi kesenjangan sosial yang terjadi pada masyarakat dan menjunjung tinggi sportifitas pada masyarakat. Sedangkan untuk program knowledge center dan ukm diharap dapat mengkatkan kualitas pendidikan dan pendapatan pada masyarakat.

Untuk merancang proyek sejenis yang perlu diperhatikan adalah alur sirkulasi pengunjung dan bagaimana suasana ruang yang ingin ditimbulkan. Alur sirkulasi dibuat dengan jelas dan berkaitan dengan apa yang hendak ditemui pengunjung terlebih dahulu agar pengunjung merasa nyaman. Suasana ruang yang ingin ditimbulkan sebaiknya memberi unsur ketenangan dan penyembuhan dengan kehadiran unsur alam. Metode perancangan yang sebaiknya digunakan adalah metode analisis tapak secara makro hingga mikro sehingga proyek tanggap terhadap lingkungannya dan memberi dampak positif bagi lingkungan. Penulis menyarankan agar hasil rancangan bangunan sejenis lebih bersifat bersih (cleanliness) dari segi arsitektur. Dan terakhir penulis ingin memberikan saran bagi pemerintah Provinsi DKI Jakarta agar lebih memperhatikan sarana sosial bagi masyarakat yang memiliki tingkat stress yang tinggi, sehingga dapat mengurangi kesenjangan sosial dan gesekan sosial antar kalangan masyarakat.

\section{REFERENSI}

Aguidin, L. M. (1995). The Concept of Type in Architecture: An Inquiry Into the Nature of Architectural Form. Swiss : Federal Institute of Technology.

Ching, F.D.K. (1979). Bentuk, Ruang, dan Tatanan. Jakarta: Erlangga

Kecamatan Pulogadung Dalam Angka. (2018). < https://jaktimkota.bps.go.id/publication/ 2018/ 09/26/6ce25d14c91a99a7b09e8244/kecamatan-pulo-gadung-dalam-angka-2018.html>

Lee, C. C. M., Jacoby, S. (2011). Typological Urbanism and the Idea of the City. New York : John Wiley \& Sons Inc.

Oldenburg, R. (1999). The Great Good Place: Cafes, Coffee Shops, Bookstores, Bars, Hair Salons, and Other Hangouts at the Heart of a Community. Marlowe \& Company.

Puspito, H. (2018) . Pengertian Komunitas: Arti, Manfaat, Jenis, dan Contohnya. < https://www.maxmanroe.com/vid/sosial/pengertian-komunitas.html>

Schmidt III, Robert., Austin, Simon. ( 2016). Adaptable Architecture: Theory and practice. Routledge.

Wenger, E. et al. (2002). Cultivating Communities of Practice. Harvard Business School Press. 
